University of Nebraska - Lincoln

DigitalCommons@University of Nebraska - Lincoln

Faculty Publications from the Harold W. Manter Laboratory of Parasitology

4-1995

\title{
Phylogenetic Relationships among the Species of Pyelosomum Looss, 1899 (Digenea: Pronocephalidae)
}

Gerardo Perez-Ponce de Leon

Universidad Nacional Autonoma de Mexico, ppdleon@servidor.unam.mx

Daniel R. Brooks

University of Toronto,dnlbrooks@gmail.com

Follow this and additional works at: https://digitalcommons.unl.edu/parasitologyfacpubs

Part of the Parasitology Commons

Perez-Ponce de Leon, Gerardo and Brooks, Daniel R., "Phylogenetic Relationships among the Species of Pyelosomum Looss, 1899 (Digenea: Pronocephalidae)" (1995). Faculty Publications from the Harold W. Manter Laboratory of Parasitology. 275.

https://digitalcommons.unl.edu/parasitologyfacpubs/275

This Article is brought to you for free and open access by the Parasitology, Harold W. Manter Laboratory of at DigitalCommons@University of Nebraska - Lincoln. It has been accepted for inclusion in Faculty Publications from the Harold W. Manter Laboratory of Parasitology by an authorized administrator of DigitalCommons@University of Nebraska - Lincoln. 


\title{
PHYLOGENETIC RELATIONSHIPS AMONG THE SPECIES OF PYELOSOMUM LOOSS, 1899 (DIGENEA: PRONOCEPHALIDAE)
}

\author{
Gerardo Pérez Ponce de León and Daniel R. Brooks* \\ Instituto de Biologia, Universidad Nacional Autónoma de México, México, D.F. Apartado Postal 70-153 C.P. 04510, México
}

\begin{abstract}
Comparative morphological study of 10 nominal species of pronocephalids forming a clade diagnosed by plump rounded bodies, sinuous ceca, and short esophagi supports the recognition of 7 species, with Pyelosomum longicaecum a junior synonym of $P$. renicapite, and $P$. solum and Myosaccus chelone $i$ species incertae sedis. Phylogenetic analysis of the 7 recognized species, based on 18 morphological transformation series, produced a single tree with a consistency index of $86 \%$. That tree suggests that Pyelosomum is paraphyletic unless Astrorchis, Epibathra, and Myosaccus are included in it. Accordingly, all are considered junior synonyms of Pyelosomum. Epibathra stenobursata is designated Pyelosomum stenobursata comb. $\mathrm{n}$.
\end{abstract}

A group of species of Pronocephalidae Looss, 1902 form a clade diagnosed by plump rounded bodies, sinuous ceca, and short esophagi (Pérez Ponce de León and Brooks, 1995). Ruiz (1946) treated species having these traits as members of Pyelosomum Looss, 1899 in a revision of the Pronocephalidae. Other taxonomic treatments, e.g., Yamaguti (1958, 1971), however, have placed the species in as many as 4 genera: Pyelosomum Looss, 1899, including Pyelosomum cochlear Looss, 1899, Pyelosomum longicaecum Luhman, 1935, Pyelosomum posterorchis Oguro, 1936, and Pyelosomum parvum Prudhoe, 1944; Epibathra Looss, 1902, including Epibathra crassa (Looss, 1901) Looss, 1902; Astrorchis Poche, 1925, including Astrorchis renicapite (Leidy, 1856) Poche, 1925; and Myosaccus Gilbert, 1938, including Myosaccus amblyrhynchus Gilbert, 1938. Subsequent to Yamaguti's (1971) study, Chattopadhyaya (1972) described Myosaccus chelonei and Pyelosomum solum in Chelonia mydas from India, and Fischthal and Acholonu (1976) described Epibathra stenobursata in Eretmochelys imbricata imbricata from Puerto Rico, bringing to 10 the number of nominal species in this clade.

This study was undertaken to establish the validity of those 10 nominal species and to discern their phylogenetic relationships. In doing so, we have evaluated the classifications proposed by Ruiz and by Yamaguti.

\section{MATERIALS AND METHODS}

\section{Specimens examined}

We examined all available published accounts and the following specimens: CHIBUNAM (Coleccion Helmintologica del Instituto de Biologia de la Universidad Nacional Autonoma de Mexico, Mexico City, Mexico): Pyelosomum cochlear: 233-10 (6), 212-11 (1); P. posterorchis: 213-4 (1); $P$. renicapite (=Astrorchis $r$.): 250-12 (8). UNSMHWML (University of Nebraska State Museum, Division of Parasitology, Harold W. Manter Laboratory, Lincoln Nebraska, U.S.A.): $P$. renicapite (=Astrorchis $r$.): 1700 (1); P. amblyrhynchi (=Myosaccus a.): 1702 (2). USNMHC (United States National Museum Helminthological Collection, Beltsville, Maryland, U.S.A.): P. cochlear: 9665 (1); P. posterorchis: 73331 (2); P. longicaecum: 8910 (1); P. renicapite (=Astrorchis r.): 74860 (1); P. stenobursata (=Epibathra s.): 73313 (1)

Received 13 April 1994; revised 18 October 1994; accepted 18 October 1994.

* Department of Zoology, University of Toronto, Toronto, Ontario, Canada M5S 1A1.

\section{Taxa recognized}

We recognize 7 valid species in this analysis. During our study, we failed to find any characters that separated $P$. longicaecum and $P$. renicapite; therefore, we consider $P$. longicaecum to be a junior synonym of $P$. renicapite. Illustrations of $M$. chelonei and $P$. solum presented by Chattopadhyaya (1972) suggest that the specimens were flattened excessively, with resultant displacement of internal organs. In addition, some aspects of the descriptions are difficult to interpret. For example, the trait that diagnoses Myosaccus as a distinct genus is a cirrus sac with a constriction in the middle, but $M$. chelone is described as lacking that constriction. Attempts to obtain specimens for examination have failed. We therefore consider $P$. solum and $M$. chelone $i$ species incertae sedis.

\section{Analyses performed}

Phylogenetic analyses were performed using the methods of phylogenetic systematics (Hennig, 1966; Wiley, 1981; Wiley et al., 1991). Al results were confirmed using the PAUP (phylogenetic analysis using parsimony) computer program version 3.1.1 (Swofford, 1993), run on a MAC IIX computer. The following options were examined: Characters: All unordered, or only multistate characters unordered, or only characters 4 and 6 unordered; outgroups: plesiomorphic conditions determined by the generic level phylogenetic tree for the Pronocephalidae (see Pérez and Brooks, 1995); optimization: Acctran, Deltran; treebuilding algorithm: Heuristic Search/Branch Swapping, Branch and Bound, Exhaustive Search.

\section{Character argumentation}

We identified the following characters and their states for use in phylogenetic analysis (characters are listed in order of their appearance in Table I). The character argumentation for each character:

1) Ceca. The plesiomorphic condition is straight ceca (0). Pyelosomum cochlear, $P$. posterorchis, $P$. crassum, and $P$. amblyrhynchi possess ceca that extend in a sinuous manner posteriorly from the cecal bifurcation (1); $P$. parvum and $P$. renicapite possess serpentine ceca (2).

2) Mehlis gland. The plesiomorphic condition is postovarian Mehlis glands (0); the Mehlis glands in $P$. parvum and $P$. renicapite are lateral to the ovary (1).

3) Anterior ends of the ceca. The plesiomorphic condition is for the ceca to extend posteriorly or posterolaterally from the cecal bifurcation $(0)$; the ceca in $P$. parvum and $P$. renicapite loop anteriorly before passing posteriorly (1).

4) Egg size. The plesiomorphic condition is eggs $42-60 \mu \mathrm{m}$ long (0); $P$. renicapite and $P$. parvum have eggs $32-40 \mu \mathrm{m}$ long (1). Pyelosomum stenobursata was described as having eggs 32-39 $\mu \mathrm{m}$ long, but the single specimen upon which the description is based is very young and the eggs are not fully developed. Consequently, we assign the plesiomorphic condition to this species.

5) Cecal tips. The plesiomorphic condition is cecal tips pointing directly posteriorly (0); in $P$. renicapite and $P$. posterorchis, the cecal tips point medially (1), and in $P$. parvum, the cecal tips point laterally (2).

6) Anterior extent of vitellaria. The plesiomorphic condition is vi- 
telline follicles extending anteriorly at least to the middle of the body, and usually somewhat farther anteriorly (0); in P. stenobursata and $P$. parvum the vitelline follicles do not extend anteriorly to the middle of the body (1).

7) Egg filaments. The plesiomorphic condition for this character is 2 filaments ( 1 at either end of the egg) (0); $P$. cochlear, $P$. posterorchis, $P$. crassum, $P$. stenobursata, and $P$. amblyrhynchi have more than 2 filaments (1), and $P$. renicapite lacks egg filaments (2).

8) Orientation of testes relative to ceca. The plesiomorphic condition is extracecal testes $(0) ; P$. renicapite, $P$. posterorchis, $P$. crassum, $P$. stenobursata, and $P$. amblyrhynchi all exhibit testes that lie ventral to the ceca (1).

9) Structure of vitellaria. The plesiomorphic condition is follicular vitellaria $(0) ; P$. renicapite has acinous vitellaria (1).

10) Position of cirrus sac. The plesiomorphic condition is intercecal cirrus sacs (0); $P$. renicapite has an extracecal cirrus sac (1).

11) Anterior extent of uterine coils. The plesiomorphic condition is uterine coils not extending anterior to the posterior end of the cirrus sac (0); $P$. cochlear has uterine loops extending anterior to the posterior end of the cirrus sac (1).

12) Relative development of the prostatic complex. The plesiomorphic condition is a relatively small prostatic complex with thinly muscled walls (0); $P$. crassum and $P$. stenobursata have well-developed prostatic complexes with thin walls (1); and $P$. amblyrhynchi has a welldeveloped prostatic complex with extremely thickly muscled walls (2).

13) Position of vitellaria. The plesiomorphic condition is vitelline follicles or acini lying ventral to the ceca as well as lateral to them (0); $P$. crassum, $P$. stenobursata, and $P$. amblyrhynchi have extracecal vitellaria only (1).

14) Relative degree of glandulation of metraterm. The plesiomorphic condition is a metraterm surrounded by relatively few gland cells $(0)$; $P$. crassum has abundant gland cells lying along the metraterm (1).

15) Lateral extent of uterine loops. The plesiomorphic condition for Pyelosomum is uterine loops that are partly extracecal (0); $P$. crassum, and $P$. amblyrhynchi have intercecal uterine loops (1). For pronoceph-
TABle I. Data matrix for Pyelosomum.*

\begin{tabular}{lllllllllllllllllllllll}
\hline PA & 2 & 1 & 1 & 1 & 2 & 1 & 0 & 0 & 0 & 0 & 0 & 0 & 0 & 0 & 0 & 0 & 0 & 0 & 1 & 1 \\
RE & 2 & 1 & 1 & 1 & 1 & 0 & 2 & 1 & 1 & 1 & 0 & 0 & 0 & 0 & 0 & 0 & 1 & 0 & 1 & 1 \\
CO & 1 & 0 & 0 & 0 & 0 & 0 & 1 & 0 & 0 & 0 & 1 & 0 & 0 & 0 & 0 & 0 & 0 & 0 & 1 & 1 \\
PO & 1 & 0 & 0 & 0 & 1 & 0 & 1 & 1 & 0 & 0 & 0 & 1 & 0 & 0 & 0 & 0 & 0 & 0 & 1 & 1 \\
CR & 1 & 0 & 0 & 0 & 0 & 0 & 1 & 1 & 0 & 0 & 0 & 1 & 1 & 1 & 1 & 0 & 1 & 0 & 1 & 1 \\
ST & 1 & 0 & 0 & 0 & 0 & 1 & 1 & 1 & 0 & 0 & 0 & 1 & 1 & 1 & 0 & 0 & 1 & 1 & 1 & 1 \\
AM & 1 & 0 & 0 & 0 & 0 & 0 & 1 & 1 & 0 & 0 & 0 & 2 & 1 & 0 & 1 & 1 & 1 & 0 & 1 & 1 \\
\hline
\end{tabular}

* $\mathrm{PA}=P$. parvum $; \mathrm{RE}=P$. renicapite $; \mathrm{CO}=P$. cochlear, $\mathrm{PO}=P$. posterorchis; $\mathrm{CR}=P$. crassum $; \mathrm{ST}=P$. stenobursata $; \mathrm{AM}=P$. amblyrhynchi. $0=$ Plesiomorphic; 1,2 = apomorphic conditions.

alids as a whole, intercecal uterine loops are plesiomorphic, so this represents an evolutionary reversal.

16) Shape of cirrus sac. The plesiomorphic condition is elongate cirrus sacs (0); $P$. crassum and $P$. amblyrhynchi have cirrus sacs that are spherical or club-shaped posteriorly (1).

17) Testes shape. The plesiomorphic condition is spherical or subspherical testes (0); $P$. renicapite, $P$. crassum, $P$. stenobursata, and $P$. amblyrhynchi have lobate testes (1).

18) Posterior extent of vitellaria. The plesiomorphic condition is vitelline follicles (or acini) not extending posterior to the anterior margin of the testes (0); $P$. stenobursata exhibits vitelline follicles extending posteriorly to the anterior margin of the testes (1).

19) Esophagus length. The plesiomorphic condition is a relatively long esophagus (0); a short esophagus (1) is a synapomorphy for Pyelosomum (see also Pérez Ponce de León and Brooks, 1995).

20) Body shape. The plesiomorphic condition is relatively elongate bodies (0); relatively plump bodies (1) is a synapomorphy for Pyelosomum (see also Pérez Ponce de León and Brooks, 1995).

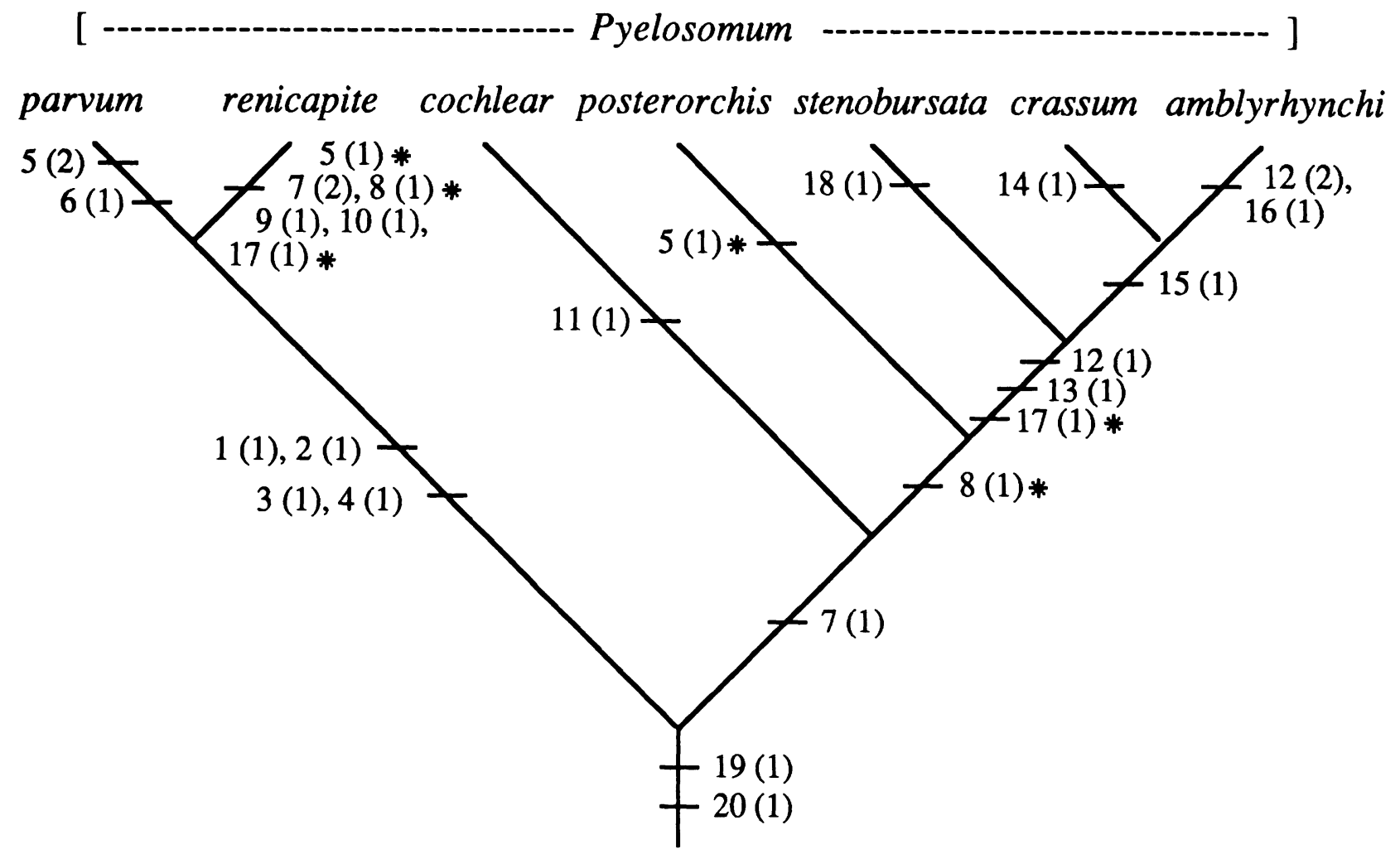

FIGURE 1. Phylogenetic tree for 6 species of Pyelosomum. Numbers accompanying slash marks on the tree indicate putative synapomorphies (character number followed by character state in parentheses) supporting the phylogenetic relationships. For identities of characters, refer to text. *, Homoplasious character state. 


\section{RESULTS}

Phylogenetic analyses of the 7 species we consider valid, using all combinations of the above options, produced a single most parsimonious phylogenetic tree (Fig. 1) with a consistency index of $86 \%$. The tree suggests that Pyelosomum is paraphyletic unless Astrorchis, Epibathra, and Myosaccus are included in it. This supports the synonymies proposed by Ruiz (1946). Accordingly, E. stenobursata Fischthal and Acholonu, 1976 becomes $P$. stenobursata (Fischthal and Acholonu, 1976) comb. n.

\section{DISCUSSION}

As with the pronocephalids as a whole, Pyelosomum is a group that primitively and predominantly comprises parasites of marine turtles, and which occurs worldwide. The highly derived position of $P$. amblyrhynchi in the phylogenetic tree of Pyelosomum argues strongly that this species inhabits the Galapagos iguana as the result of a host switch. From the biogeographic perspective, we note that at present, $P$. parvum and $P$. amblyrhynchi are known only from the Pacific Ocean, $P$. crassum and $P$. stenobursata are known only from the Atlantic Ocean, whereas $P$. cochlear, $P$. renicapite, and $P$. posterorchis are known from both.

\section{ACKNOWLEDGMENTS}

Funding for this study was provided by DGAPA-UNAM, in the form of a fellowship to G.P. for research at the University of Toronto; by the Natural Sciences and Engineering Research Council of Canada, in the form of NSERC operating grant A7696 to D.B. Special thanks to Mary H. Pritchard, curator, and Skip Sterner, collection manager, Division of Parasitology, University of Nebraska State Museum and J. Ralph Lichtenfels, curator, and Patricia Pilitt, United States National Helmintho- logical Collection for the loan of specimens; to David Blair, James Cook University, Queensland, Australia, for reprints of pertinent articles; and to Deborah A. McLennan for the production of graphics.

\section{LITERATURE CITED}

Chattopadhyaya, D. R. 1972. Studies on the trematode parasite [sic] of reptiles found in India. Contribution to our knowledge of the family Pronocephalidae Looss, 1902. Rivista di Parassitologia 33: 99-124.

Fischthal, J. H., AND A. D. ACholonu. 1976. Some digenetic trematodes from the Atlantic hawksbill turtle, Eretmochelys imbricata imbricata (L.), from Puerto Rico. Proceedings of the Helminthological Society of Washington 43: 174-185.

HenNIG, W. 1966. Phylogenetic systematics. University of Illinois Press, Urbana, Illinois, 263 p.

Pérez Ponce de León, G., AND D. R. Brooks. 1995. Phylogenetic relationships of the genera of the Pronocephalidae Looss, 1902 (Digenea: Paramphistomiformes). Journal of Parasitology 81: 000000 .

RuIz, J. M. 1946. Pronocephalidae (Trematoda). Estudos des especies brasileiros e revisao da familia. Memorias do instituto Butantan 19: 249-372.

SwOFFORD, D. 1993. Phylogenetic analysis using parsimony, version 3.1.1. Illinois Natural History Survey, Urbana, Illinois.

Wiley, E. O. 1981. Phylogenetics: The theory and practice of phylogenetic systematics. Wiley-Interscience, New York, New York, $439 \mathrm{p}$.

Wiley, E. O., D. Siegel-Causey, D. R. Brooks, AND V. A. FunK. 1991. The compleat cladist: A primer of phylogenetic procedures. University of Kansas Museum of Natural History Press, Lawrence, Kansas, 158 p.

YAmAGUTI, S. 1958. Systema Helminthum. Volume I. The digenetic trematodes of vertebrates. Interscience Publishers, Inc., New York, $1,575 \mathrm{p}$.

YAMAGUTI, S. 1971. Digenetic trematodes of vertebrates. Keigaku Publishing Company, Tokyo, Japan, 1,074 p. 